\title{
Matrix Effects on the Degradation of Gemfibrozil, Hydrochlorothiazide, and Naproxen by Heterogeneous Photocatalysis
}

\author{
Cleiseano E. S. Paniagua, ${ }^{a}$ Eduardo O. Marson, ${ }^{a}$ Ivo A. Ricardo, ${ }^{a, b}$ Vinícius A. B. Paiva, ${ }^{a}$ \\ Bárbara R. Gonçalves ${ }^{a}$ and Alam G. Trovó ${ }^{\circledR} * a$ \\ ${ }^{a}$ Instituto de Química, Universidade Federal de Uberlândia, 38400-902 Uberlândia-MG, Brazil \\ ${ }^{b}$ Departamento de Ciências Naturais e Matemática, Universidade Save, 1200, Chongoene, \\ Gaza, Mozambique
}

\begin{abstract}
The degradation of a pharmaceutical mixture (gemfibrozil, hydrochlorothiazide and naproxen) by $\mathrm{TiO}_{2} / \mathrm{UV}$-A in different aqueous matrices was evaluated. The matrix components affected the operational conditions, rate constants, and removal efficiency of the pharmaceuticals, as well as toxicity. For sewage treatment plant effluent, a $\mathrm{TiO}_{2}$ concentration three-fold higher $\left(450 \mathrm{mg} \mathrm{L}^{-1}\right)$ and an irradiation time 1.5-3 times longer were required to reach the same efficiency of degradation as the pharmaceuticals in deionized water and surface water matrices. An improvement in the rate constants and the removal efficiency of the pharmaceuticals was achieved by adding $6 \mathrm{mg} \mathrm{L}^{-1}$ of $\mathrm{H}_{2} \mathrm{O}_{2}$ and $150 \mathrm{mg} \mathrm{L}^{-1}$ of $\mathrm{TiO}_{2}$ in deionized water and surface water, but not in the sewage treatment plant effluent, due to the coupling of $450 \mathrm{mg} \mathrm{L}^{-1}$ of $\mathrm{TiO}_{2}$ and $50-200 \mathrm{mg} \mathrm{L}^{-1}$ of $\mathrm{H}_{2} \mathrm{O}_{2}$. Overall, $\mathrm{TiO}_{2} / \mathrm{UV}$-A efficiently degraded all compounds, but an additional step is needed for the removal of residual toxicity.
\end{abstract}

Keywords: advanced oxidation process, contaminants of emerging concern, environmental aqueous matrices, operational conditions, titanium dioxide

\section{Introduction}

Pharmaceuticals are commonly detected and quantified in environmental aqueous matrices at trace levels (ng $\mathrm{L}^{-1}$ to $\mu \mathrm{g} \mathrm{L}^{-1}$ ) due to their low removal efficiency in municipal wastewater treatment plants. ${ }^{1,2}$ Among them, gemfibrozil (GEM), hydrochlorothiazide (HCTZ) and naproxen (NAP) (Figure S1, Supplementary Information (SI) section) have been detected at levels of 8.91-15.12, ${ }^{3} 33.13,{ }^{4}$ and $0.0038-0.0133 \mathrm{ng} \mathrm{L}^{-1}, 5$ respectively. In addition, these compounds were detected in influents and sewage effluents at levels higher than $1000 \mathrm{ng} \mathrm{L}^{-1}$ in most samples of the five sewage treatment plants (STP) monitored in Spain over a period of two years. ${ }^{6}$ Thus, these compounds were chosen as representative compounds for different classes of contaminants of emerging concern (CEC) because of their frequent occurrence in different aqueous matrices and their environmental relevance. Although present at low concentrations, they cause deleterious effects to aquatic biota. $^{?}$

*e-mail: alamtrovo@ufu.br
A previous study of our research group ${ }^{8}$ showed that the degradation of these pharmaceuticals by UV-C and $\mathrm{UV}-\mathrm{C} / \mathrm{H}_{2} \mathrm{O}_{2}$ processes was strongly affected by the matrix composition. These results have motivated the evaluation of the degradation of these target compounds by heterogeneous photocatalysis, since this process has the advantage that sunlight can be used as a source of radiation, and the process has applications over a wide $\mathrm{pH}$ range. ${ }^{9}$

Alvarez-Corena et al. ${ }^{10}$ evaluated the influence of $\mathrm{pH}$ (3-9) and $\mathrm{TiO}_{2}$ dosage (0.1-2.5 $\left.\mathrm{g} \mathrm{L}^{-1}\right)$ by $\mathrm{TiO}_{2} / \mathrm{UV}-\mathrm{C}$ during the simultaneous degradation of five contaminants including gemfibrozil in deionized water (DW) (initially with $2 \mathrm{mg} \mathrm{L}^{-1}$ for each compound). Optimal results were obtained with $1.5 \mathrm{~g} \mathrm{~L}^{-1}$ of the photocatalyst and at $\mathrm{pH}$ 5.0. Márquez et al. ${ }^{11}$ evaluated the coupling of $\mathrm{O}_{3}$ and $\mathrm{TiO}_{2}$ under solar radiation, aiming to degrade a mixture of pharmaceuticals (atenolol, hydrochlorothiazide, ofloxacin and trimethoprim; $10 \mathrm{mg} \mathrm{L}^{-1}$ of each compound) in DW, with a UV-A radiation dose of $0.94 \mathrm{~kJ}$ per mg pharmaceutical, obtaining $100 \%$ degradation efficiency for hydrochlorothiazide and ofloxacin and a maximum efficiency of $80 \%$ for the remaining pharmaceuticals. In 
assessing the degradation of 60 and $440 \mathrm{mg} \mathrm{L}^{-1}$ of NAP in DW by $\mathrm{TiO}_{2}$ under UV-C and solar radiation using $0.4 \mathrm{~g} \mathrm{~L}^{-1}$ of the photocatalyst at a $\mathrm{pH}$ of 6.5 , Jallouli et al. ${ }^{12}$ obtained higher NAP (98\%) removals with the heterogeneous photocatalysis process compared to $83 \%$ removal efficiency obtained with photolysis.

In parallel, the influence of chloride and phosphate anions (isolated and mixture) was also evaluated on the removal of $30 \mathrm{mg} \mathrm{L}^{-1}$ of NAP using heterogeneous photocatalysis. ${ }^{13}$ The influence of the matrix components (DW and STP effluent) on the operational conditions of heterogeneous photocatalysis was also evaluated in an experiment involving the degradation of $0.05 \mathrm{~g} \mathrm{~L}^{-1}$ of metoprolol. ${ }^{14} \mathrm{~A}$ similar study ${ }^{15}$ was carried out with ibuprofen, with concentrations of 0.006 to $213 \mathrm{mg} \mathrm{L}^{-1}$ in DW, surface water (SW), and effluent from the pharmaceutical industry. Generally, it was found that $(i)$ the relative natural abundance of optically active substances limits the penetration of light; (ii) the possible elimination of hydroxyl radicals and generation of less reactive radical species may be due to the chloride, sulfate and bicarbonate anions and, organic matter of the matrix; and (iii) inorganic ions and organic matter may also adsorb on the catalyst surface, inhibiting the production of $\mathrm{HO}^{*} .^{13,16}$

As it can been observed, most of the scientific papers ${ }^{10-13}$ concerning degradation of these target compounds were performed in DW, and by using high concentrations of the target compounds (2-440 $\mathrm{mg} \mathrm{L}^{-1}$ ), values well above those detected in real matrices were obtained. Since this technology is affected by the operational conditions (temperature, concentrations of the target compounds, $\mathrm{TiO}_{2}$ and $\mathrm{H}_{2} \mathrm{O}_{2}, \mathrm{pH}$, inorganic anions, natural organic matter (NOM), etc.) and since, in the present work, low concentrations (413-536 $\mu \mathrm{g} \mathrm{L}^{-1}$ ) of these pharmaceuticals were evaluated, the best experimental conditions were specific to each matrix and they had to be determined separately. In addition, monitoring the toxicity profile for each treated matrix is important once the mineralization monitoring is no longer feasible for real matrices. This happens because it is not possible to distinguish between the mineralization of the pharmaceuticals and the NOM. Besides, according to our research in literature, no comparative study of the simultaneous degradation of these target compounds at low concentrations has been performed at a natural $\mathrm{pH}$ value for each matrix, with the main operational conditions (concentration of $\mathrm{TiO}_{2}$ and $\mathrm{H}_{2} \mathrm{O}_{2}$ ) being evaluated and optimized, the kinetic parameters determined, and the toxicity monitored.

Therefore, in order to clarify this issue, this work aimed to evaluate the impact of each matrix on the operational conditions of heterogeneous photocatalysis, on the rate constants and removal efficiency of the target compounds, and on toxicity, using the results in DW (a free matrix of interfering species) as basis for comparison.

\section{Experimental}

\section{Chemicals}

The solutions were made in DW and with analyticalgrade reagents. Standards of the target pharmaceuticals (99 wt.\%) were acquired from Sigma-Aldrich (St. Louis, USA). High-performance liquid chromatography (HPLC)-grade methanol was purchased from J.T. Baker (Xalostoc, Mexico). $\mathrm{NH}_{4} \mathrm{VO}_{3}$ from Vetec (Rio de Janeiro, Brazil) was used as received. The remaining reagents employed in this work, which were titanium dioxide $\mathrm{P} 25$ (Degussa/Evonick, Essen, Germany), $\mathrm{C}_{4} \mathrm{~K}_{2} \mathrm{O}_{9} \mathrm{Ti} \cdot 2 \mathrm{H}_{2} \mathrm{O}$, $\mathrm{H}_{2} \mathrm{O}_{2}$ (30 wt.\%), $\mathrm{Na}_{2} \mathrm{SO}_{3}$, and 2-propanol, all from Synth (São Paulo, Brazil), were used without further purification.

\section{Sampling of the environmental aqueous matrices}

The sampling was carried out in municipal wastewater treatment plants and the main physical-chemical parameters of the samples were determined (Table S1, SI section). The collection took place in the autumn and spring of 2017. The sampling of SW was performed from a river used to supply water to the city of Uberlândia, Brazil (18 $55^{\prime} 08^{\prime}$ 'S, $\left.48^{\circ} 16^{\prime} 37^{\prime \prime} \mathrm{W}\right)$. The sampling of STP effluent was carried out after complete treatment in the municipal wastewater, which consists of steps of: (i) removal of coarse solids and sand; (ii) use of upflow anaerobic reactors; and (iii) use of a FlotFlux ${ }^{\circledR}$ channel based on sequential application of coagulationflocculation-flotation. The SW and STP effluent samples were kept at $4{ }^{\circ} \mathrm{C}$ for two to three weeks while conducting the photodegradation experiments.

\section{Photolytic and photocatalytic experiments}

The simultaneous degradation of the pharmaceuticals (451 $\mu \mathrm{g} \mathrm{L}^{-1}$ of GEM, $536 \mu \mathrm{g} \mathrm{L}^{-1}$ of HCTZ and $413 \mu \mathrm{g} \mathrm{L}^{-1}$ of NAP) was performed by irradiating a $500-\mathrm{mL}$ aqueous solution. An amber glass flask of $4.3 \mathrm{~cm}$ of depth and $15.5 \mathrm{~cm}$ of diameter was used as reactor (Figure S2, SI section). The experiments were performed under constant magnetic stirring at $25-28^{\circ} \mathrm{C}$ (room temperature). The initial concentrations of the pharmaceuticals were settled to allow for monitoring their degradation by direct injection of the sample into the HPLC system, without the pre-concentration step, with efficiencies above $95 \%$. 
Two $10 \mathrm{~W}$, low pressure, black-light lamps $\left(\lambda_{\max }=365 \mathrm{~nm}\right)$ (Figure S2, SI section) were placed side by side at a distance of $3.5 \mathrm{~cm}$ between them and at $1 \mathrm{~cm}$ of height from the top of the flask and used as a radiation source. A radiometer PMA 2100 Solar Light Co. equipped with a UV-A (320-400 nm) sensor was used to monitor de irradiance and an average of $32 \mathrm{~W} \mathrm{~m}^{-2}$ was obtained.

First, at an initial $\mathrm{pH}$ of 5.8-6.0 (the natural $\mathrm{pH}$ of these matrices), the influence of $\mathrm{TiO}_{2}$ concentration (50-200 $\mathrm{mg} \mathrm{L}^{-1}$ ) on the degradation of the target compounds in DW and SW was evaluated. The same study was performed with $\mathrm{STP}^{1}$ effluent at a $\mathrm{pH}$ of 7.7 (the natural $\mathrm{pH}$ for this matrix); however, higher concentrations of $\mathrm{TiO}_{2}$ (150-600 $\mathrm{mg} \mathrm{L}^{-1}$ ) were used due to its higher complexity. Then, by using the optimal concentrations of $\mathrm{TiO}_{2}$ for each matrix (150 mg L ${ }^{-1}$ for DW and $\mathrm{SW}$ and $450 \mathrm{mg} \mathrm{L}^{-1}$ for STP $^{1}$ effluent), the combination with $\mathrm{H}_{2} \mathrm{O}_{2}$ was studied. Different concentrations of this reagent $\left(1-9 \mathrm{mg} \mathrm{L}^{-1}\right.$ for DW and SW and, 50-200 $\mathrm{mg} \mathrm{L}^{-1}$ for $\mathrm{STP}^{1}$ effluent) were evaluated taking into account the highest dissolved organic carbon (DOC) concentration (Table S1, SI section). The concentrations of $\mathrm{H}_{2} \mathrm{O}_{2}$ for each matrix were chosen based on a previous work of our group. ${ }^{8}$

Using the ideal conditions $\left(150 \mathrm{mg} \mathrm{L}^{-1}\right.$ of $\mathrm{TiO}_{2}$ and $6 \mathrm{mg} \mathrm{L}^{-1}$ of $\mathrm{H}_{2} \mathrm{O}_{2}$ for DW and SW and only $450 \mathrm{mg} \mathrm{L}^{-1}$ of $\mathrm{TiO}_{2}$ for $\mathrm{STP}^{1}$ effluent), the irradiation time was doubled from 120 to 240 min for the DW and SW, and from 240 to 360 min for the STP effluent while monitoring the evolution of toxicity as well as mineralization.

\section{Chemical analyses and toxicity bioassays}

The concentrations of the target compounds were determined following the methodology described by Paiva et al. ${ }^{17}$

$\mathrm{H}_{2} \mathrm{O}_{2}$ was spectrophotometrically quantified by the titanium oxalate method when $\mathrm{H}_{2} \mathrm{O}_{2}$ concentrations below $50 \mathrm{mg} \mathrm{L}^{-1}$ were used, ${ }^{18}$ and the metavanadate method was used when monitoring $\mathrm{H}_{2} \mathrm{O}_{2}$ concentrations that were greater than $50 \mathrm{mg} \mathrm{L}^{-1} .{ }^{19}$ Mineralization was monitored by carbon analyzer equipment (Shimadzu TOC VCPN model).

Acute toxicity toward V. fischeri bacteria followed the Brazilian norm. ${ }^{20}$ The bioluminescence emitted by the V. fischeri bacteria to the non-treated and treated solutions obtained during the heterogeneous photocatalysis process (after adjustment of the salinity to $2 \%$ ) was monitored. The values obtained were compared with a solution of $2 \%$ $\mathrm{NaCl}$, used as a control. A solution of $13.4 \mathrm{mg} \mathrm{L}^{-1}$ of $\mathrm{Cr}^{6+}$ was employed as a positive toxicant control. A thermoblock was used to maintain the temperature at $15{ }^{\circ} \mathrm{C}$. In order to remove the residual $\mathrm{H}_{2} \mathrm{O}_{2}$ present in the samples, a volume of $150 \mu \mathrm{L}$ of $2.0 \mathrm{~g} \mathrm{~L}^{-1}$ bovine catalase was added to the samples followed by stirring for $30 \mathrm{~s}$.

Prior to analyses, the removal of the suspended $\mathrm{TiO}_{2}$ particles was carried out through filtration by membranes of $0.45 \mu \mathrm{m}$ mean pore size.

\section{Results and Discussion}

\section{Adsorption-desorption equilibrium experiments}

Since in heterogeneous photocatalysis the degradation of the compounds occurs on the surface of the photocatalyst, the adsorption-desorption equilibrium has important consequences for the treatment. ${ }^{21}$ To determine the equilibrium time between the catalyst and the target compounds, an experiment was carried out in DW at $\mathrm{pH}$ of 6.0 (the natural $\mathrm{pH}$ of this matrix) using $80 \mathrm{mg} \mathrm{L}^{-1}$ of $\mathrm{TiO}_{2}$ (Figure S3, SI section).

As it can be observed in the results presented in Figure S3, extending the time to $30 \mathrm{~min}$, a maximum adsorption of $26-34 \%$ was obtained for all target compounds, followed by complete desorption after $120 \mathrm{~min}$. Once degradation of the target compounds by heterogeneous photocatalysis occurs on the surface of the catalyst, either by a direct (holes) or indirect (hydroxyl radicals) mechanism, ${ }^{21,22}$ and based on the results of the Figure $\mathrm{S} 3$ after $120 \mathrm{~min}$, it is expected to find no difference in degradation of the target compounds irradiating the solutions without and with equilibrium establishment. To confirm this hypothesis, two sets of experiments were carried out: one in which activation of the black-light lamp occurred after 120 min (Figure S4, SI section, open symbols) and the other in which the solution was irradiated just after the addition of $\mathrm{TiO}_{2}$ (Figure $\mathrm{S} 4$, solid symbols). No difference in the degradation of the pharmaceuticals was found. Thus, additional experiments were carried out by activating the black-light lamp soon after the addition of $\mathrm{TiO}_{2}$.

In addition, to verify the main mechanism responsible (direct or indirect) for the degradation of pharmaceuticals during heterogeneous photocatalysis, experiments were performed using $80 \mathrm{mg} \mathrm{L}^{-1}$ of $\mathrm{TiO}_{2}$ at $\mathrm{pH}$ of 6.0 , with the 2-propanol varied from 5 to $50 \mathrm{mmol} \mathrm{L}^{-1}$ (Figure S5, SI section). The addition of 2-propanol inhibited the degradation of the target compounds, but no complete inhibition was obtained by ranging the 2-propanol concentration from 5 to $50 \mathrm{mmol} \mathrm{L}^{-1}$ (Figure S5). In addition, a distinct profile during the degradation of HCTZ (Figure S5b, SI section) can be observed when compared to GEM and NAP (Figures S5a and S5c, SI section). High inhibition of the degradation of HCTZ occurred using 
$25 \mathrm{mmol} \mathrm{L}^{-1}$ of 2-propanol (Figure S5b), compared to the inhibition of GEM and NAP in absence of 2-propanol (Figures S5a and S5c). These results indicate that major degradation of HCTZ was through an indirect mechanism via the $\mathrm{HO}^{*}$, since 2-propanol is a good trapping agent for $\mathrm{HO}^{*}\left(\mathrm{k}=1.9 \times 10^{9} \mathrm{~L} \mathrm{~mol}^{-1} \mathrm{~s}^{-1}\right){ }^{23,24}$ In contrast, the majority degradation of GEM and NAP primarily occurred via direct mechanism by holes $\left(\mathrm{h}^{+}\right)$, since a lower inhibition of the degradation of GEM and NAP (Figures S5a and S5c) occurred using $25 \mathrm{mmol} \mathrm{L}^{-1}$ of 2-propanol in comparison to HCTZ (Figure S5b).

\section{Influence of $\mathrm{TiO}_{2}$ concentration}

The determination of the optimal $\mathrm{TiO}_{2}$ concentration is crucial to ensure the maximum degradation of the pharmaceuticals involved in this study. ${ }^{25,26}$ Therefore, different dosages of $\mathrm{TiO}_{2}$ were tested in the aqueous matrices, aiming to verify how the matrix components affect this operational parameter in the degradation of the pharmaceuticals (Figure 1). The kinetic parameters (Table S2, SI section) were determined by plotting the results of $\ln \left(\frac{\mathrm{C}}{\mathrm{C}_{0}}\right)$ (C is the target compound concentration at a determined time $\mathrm{X}, \mathrm{C}_{0}$ is the initial target compound concentration) versus time, which is characteristic of a pseudo-first-order kinetics model.

An improvement in the degradation rates of the pharmaceuticals was obtained by increasing the $\mathrm{TiO}_{2}$ dosage (compared to experiments in which no $\mathrm{TiO}_{2}$ was used) (Figure 1). A quantitative comparison of the results in terms of the kinetic parameters (rate constant, $\mathrm{k}$; and half-life, $\mathrm{t}_{1 / 2}$ ) was also made (Table S2, SI section). For DW and SW matrices, an increase in $\mathrm{k}$ and, consequently, a decrease in the $\mathrm{t}_{1 / 2}$ was observed using $150 \mathrm{mg} \mathrm{L}^{-1} \mathrm{TiO}_{2}$ (Table S2 and Figure 1). In addition, a negative effect occurred when using $200 \mathrm{mg} \mathrm{L}^{-1}$ of $\mathrm{TiO}_{2}$ due to a raise in the turbidity and aggregation of the catalyst particles, which limits light penetration and reduces the surface area of the active sites, respectively. ${ }^{25,27}$ Similar behavior was observed
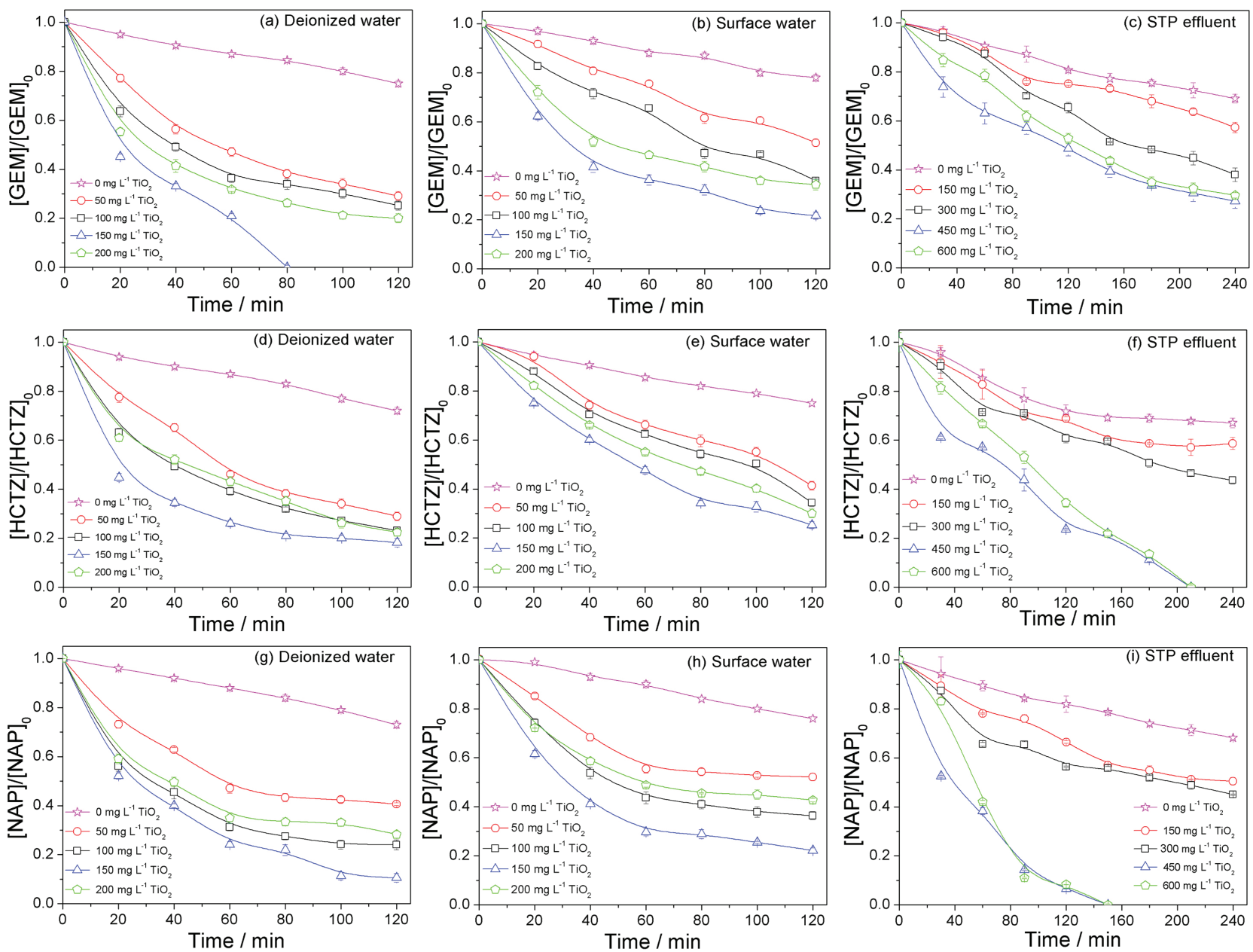

Figure 1. Influence of the $\mathrm{TiO}_{2}$ concentration on the degradation of (a-c) gemfibrozil (GEM); (d-f) hydrochlorothiazide (HCTZ); and (g-i) naproxen (NAP) in different aqueous matrices. The initial conditions were the following: $[\mathrm{GEM}]=451 \mu \mathrm{g} \mathrm{L}{ }^{-1}$, [HCTZ] $=536 \mu \mathrm{g} \mathrm{L}^{-1}$, $[\mathrm{NAP}]=413 \mu \mathrm{g} \mathrm{L}{ }^{-1}$, $\mathrm{pH}=5.8-6.0 \mathrm{in}$ DW and SW, and 7.7 in STP ${ }^{1}$ effluent. 
for the STP effluent matrix; there was an improvement in the value of $\mathrm{k}$ up to $450 \mathrm{mg} \mathrm{L}^{-1}$ of $\mathrm{TiO}_{2}$, followed by a negative effect when using $600 \mathrm{mg} \mathrm{L}^{-1}$ of $\mathrm{TiO}_{2}$ (Table S2 and Figure 1).

In addition, the composition of the aqueous matrices significantly affected the $\mathrm{k}$ values; the higher their complexity (STP effluent $>\mathrm{SW}>\mathrm{DW}$ ), the lower the $\mathrm{k}$ values and the higher the $t_{1 / 2}$ of the target compounds (Table S2, SI section). Although the same $\mathrm{TiO}_{2}$ concentration $\left(150 \mathrm{mg} \mathrm{L}^{-1}\right)$ resulted in the best results for $\mathrm{k}$ and $\mathrm{t}_{1 / 2}$ for the DW and SW, respectively, lower values of $\mathrm{k}$ and higher values of $\mathrm{t}_{1 / 2}$ were obtained in SW when compared to DW (Table S2). This is justified by the matrix components (Table S1, SI section), which was $7.3 \mathrm{mg} \mathrm{C} \mathrm{L}^{-1}$ of dissolved inorganic carbon (DIC), equivalent to $37 \mathrm{mg} \mathrm{L}^{-1} \mathrm{HCO}_{3}^{-}, 1.4 \mathrm{mg} \mathrm{L}^{-1} \mathrm{Cl}^{-}, 0.8 \mathrm{mg} \mathrm{L}^{-1}$ $\mathrm{SO}_{4}{ }^{2-}, 0.2 \mathrm{mg} \mathrm{L}^{-1} \mathrm{NH}_{4}{ }^{+}$and less than $0.05 \mathrm{mg} \mathrm{L}^{-1} \mathrm{HPO}_{4}{ }^{2-}$, and by the NOM (6.7 $\mathrm{mg} \mathrm{C} \mathrm{L}^{-1}$ of DOC). The NOM can absorb the target compounds as they compete for $\mathrm{TiO}_{2}$ adsorption sites. This is in accordance with a previous research ${ }^{28}$ that studied the influencing power of inorganic salts on the photocatalytic efficiency of $\mathrm{TiO}_{2}$; the amount of methylene blue $(84.2 \mu \mathrm{mol} \mathrm{L}-1)$ adsorbed on the $\mathrm{TiO}_{2}$ surface $\left(0.5 \mathrm{~g} \mathrm{~L}^{-1}\right)$ at $\mathrm{pH}$ of 6-7 decreased in the following sequence: $\mathrm{HCO}_{3}^{-}>\mathrm{HPO}_{4}{ }^{2-}>\mathrm{SO}_{4}{ }^{2-}>\mathrm{Cl}^{-}>\mathrm{NO}_{3}{ }^{-}$. At the present working $\mathrm{pH}$ of 5.8 (the natural $\mathrm{pH}$ of the $\mathrm{SW}$ matrix), the semiconductor surface is positive, with strong competition expected between the target compounds, with neutral or negative charges (Figure S6, SI section), and the major inorganic anions $\left(\mathrm{HCO}_{3}{ }^{-}, \mathrm{SO}_{4}{ }^{2-}\right.$, and $\mathrm{Cl}^{-}$; Table $\mathrm{S} 1$, SI section), justifying the reduction in $\mathrm{k}$ values (Table $\mathrm{S} 2$, SI section). In addition, there is the strong contribution of $6.7 \mathrm{mg} \mathrm{L}^{-1}$ of DOC (Table S1), which mostly inhibits the photocatalytic removal of oestrogenic activity in secondary effluent when compared to inorganic ions..$^{29}$ In parallel, these inorganic ions and DOC are also capable of competing with the target compounds through hydroxyl radicals (equations 1-5), ${ }^{30,31}$ decreasing their availability and, consequently, affecting the degradation efficiency or reacting with the holes (equation 6), generating $\mathrm{Cl}^{\cdot}$ radicals, which are then converted into $\mathrm{Cl}_{2}{ }^{-}$radicals (equation 7). ${ }^{16,29,32}$

$$
\begin{array}{ll}
\mathrm{Cl}^{-}+\mathrm{HO}^{-} \rightarrow \mathrm{ClHO}^{-} & \mathrm{k}=4.3 \times 10^{9} \mathrm{~L} \mathrm{~mol}^{-1} \mathrm{~s}^{-1} \\
\mathrm{ClHO}^{--} \rightarrow \mathrm{Cl}^{-}+\mathrm{HO}^{-} & \mathrm{k}=6.0 \times 10^{9} \mathrm{~s}^{-1} \\
\mathrm{ClHO}^{--}+\mathrm{H}^{+} \rightarrow \mathrm{Cl}^{-}+\mathrm{H}_{2} \mathrm{O} & \mathrm{k}=2.4 \times 10^{10} \mathrm{~L} \mathrm{~mol}^{-1} \mathrm{~s}^{-1}(3) \\
\mathrm{HCO}_{3}^{-}+\mathrm{HO}^{-} \rightarrow \mathrm{H}_{2} \mathrm{O}+\mathrm{CO}_{3}^{--} \mathrm{k}=8.5 \times 10^{6} \mathrm{~L} \mathrm{~mol}^{-1} \mathrm{~s}^{-1}(4) \\
\mathrm{SO}_{4}{ }^{2-}+\mathrm{HO}^{\circ} \rightarrow \mathrm{OH}^{-}+\mathrm{SO}_{4}^{--} \mathrm{k}=3.5 \times 10^{5} \mathrm{~L} \mathrm{~mol}^{-1} \mathrm{~s}^{-1} \\
\mathrm{~h}^{+}{ }_{\mathrm{BV}}+\mathrm{Cl}^{-} \rightarrow \mathrm{Cl}^{-} \\
\mathrm{Cl}^{-}+\mathrm{Cl}^{-} \rightarrow \mathrm{Cl}_{2}^{--} & \mathrm{k}=8.5 \times 10^{\circ} \mathrm{L} \mathrm{mol}^{-1} \mathrm{~s}^{-1}
\end{array}
$$

For the STP matrix, a $\mathrm{TiO}_{2}$ concentration three times higher (450 $\mathrm{mg} \mathrm{L}^{-1}$ ) was required to achieve the same degradation efficiency of the pharmaceuticals when compared to the DW and SW, which is a consequence of the high concentration of organic matter and inorganic ions (Table S1). The same profile was obtained during the degradation of ibuprofen; $1000 \mathrm{mg} \mathrm{L}^{-1}$ of $\mathrm{TiO}_{2}$ was necessary with DW and $2500 \mathrm{mg} \mathrm{L}^{-1}$ of $\mathrm{TiO}_{2}$ was required with the effluent from the pharmaceutical industry. ${ }^{15}$

Influence of $\mathrm{H}_{2} \mathrm{O}_{2}$ concentration

The coupling of $\mathrm{H}_{2} \mathrm{O}_{2}$ and $\mathrm{TiO}_{2}$ can improve the degradation of the target compounds since this minimizes recombination of the electron/hole pair and raises the production of $\mathrm{HO}^{*}$ (equation 8$)^{33}$

$\mathrm{H}_{2} \mathrm{O}_{2}+\mathrm{e}_{\mathrm{BC}}{ }^{-} \rightarrow \mathrm{HO}^{\cdot}+\mathrm{OH}^{-}$

The action of the hydrogen peroxide dosage on the degradation efficiency of the target compounds for the different aqueous matrices (Figure 2) was evaluated, and the kinetic parameters were determined (Table S3, SI section).

The efficiency of the degradation of the pharmaceuticals increased by adding $6 \mathrm{mg} \mathrm{L}^{-1}$ of $\mathrm{H}_{2} \mathrm{O}_{2}$ in the DW and SW matrices (Figure 2), contributing to the high $\mathrm{k}$ and low $\mathrm{t}_{1 / 2}$ values, respectively (Table S2, SI section). Using $9 \mathrm{mg} \mathrm{L}^{-1}$ of $\mathrm{H}_{2} \mathrm{O}_{2}$, there was a drop in $\mathrm{k}$ values and an increase in $\mathrm{t}_{1 / 2}$ values (Table $\mathrm{S} 3$, SI section). This is attributed to the excess $\mathrm{H}_{2} \mathrm{O}_{2}$ (Figures S7a and S7b, SI section), which can adsorb onto the surface of the $\mathrm{TiO}_{2}$, causing changes to its surface and its catalytic activity, ${ }^{34}$ and it can compete with the target compounds for hydroxyl radicals (equation 9) or reacting with the holes (equation 10):

$$
\begin{aligned}
& \mathrm{H}_{2} \mathrm{O}_{2}+\mathrm{HO}^{\cdot} \rightarrow \mathrm{H}_{2} \mathrm{O}+\mathrm{HO}_{2}^{\cdot} \mathrm{k}=2.7 \times 10^{7} \mathrm{~L} \mathrm{~mol}^{-1} \mathrm{~s}^{-1} \\
& \mathrm{H}_{2} \mathrm{O}_{2}+2 \mathrm{~h}_{\mathrm{BV}^{+}} \rightarrow \mathrm{O}_{2}+2 \mathrm{H}^{+}
\end{aligned}
$$

No synergistic effect on the degradation of the pharmaceuticals in the STP effluent was obtained when compared to the results in DW and SW matrices by adding $\mathrm{H}_{2} \mathrm{O}_{2}$ in the range evaluated (50-200 $\mathrm{mg} \mathrm{L}^{-1}$ ) (Figure 2 and Table S3, SI section). Thus, the consumption of $\mathrm{H}_{2} \mathrm{O}_{2}$ (Figure S7c, SI section) can be attributed to the inefficient parallel reactions presented by equations $1-5$, radical recombination (equations 11-15), or reactions between $\mathrm{H}_{2} \mathrm{O}_{2}$ and radical species, such as $\mathrm{HO}^{\circ}, \mathrm{HO}_{2}{ }^{\circ}$ (equations 9 and 16), $\mathrm{SO}_{4}^{--}$(equation 17), or radicals derived from chlorine (equations 18 and 19), which generate less reactive hydroperoxyl radicals $\left.\left(\mathrm{HO}_{2}\right)^{\circ}\right)^{35}$ Thus, in the STP effluent matrix, the addition of $\mathrm{H}_{2} \mathrm{O}_{2}$ is unnecessary. 

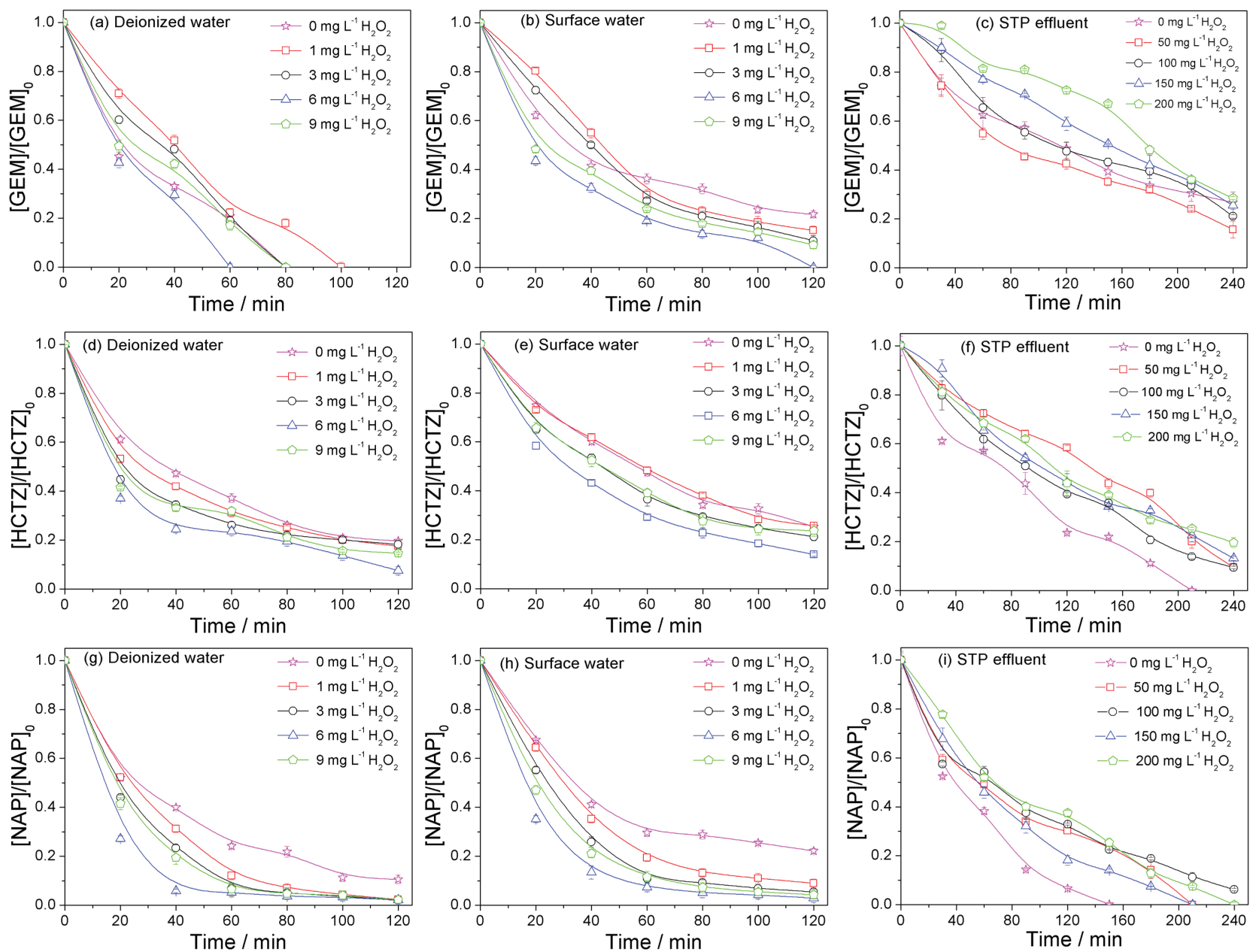

Figure 2. Influence of the $\mathrm{H}_{2} \mathrm{O}_{2}$ dosage on the degradation efficiency of (a-c) gemfibrozil (GEM); (d-f) hydrochlorothiazide (HCTZ); and (g-i) naproxen (NAP) in different aqueous matrices during heterogeneous photocatalysis. The initial conditions were the following: [GEM] $=451 \mu \mathrm{g} \mathrm{L}{ }^{-1},\left[\mathrm{HCTZ}^{-}=536 \mu \mathrm{g} \mathrm{L}{ }^{-1}\right.$, $[\mathrm{NAP}]=413 \mu \mathrm{g} \mathrm{L}^{-1},\left[\mathrm{TiO}_{2}\right]=150 \mathrm{mg} \mathrm{L}-1$ at $\mathrm{pH}=5.8-6.0$ (natural $\mathrm{pH}$ of the $\mathrm{DW}$ and $\mathrm{SW}$ solutions); $\left[\mathrm{TiO}_{2}\right]=450 \mathrm{mg} \mathrm{L}-1$ at $\mathrm{pH}=7.7$ (natural $\mathrm{pH}$ of the STP $^{1}$ effluent).

$$
\begin{aligned}
& \mathrm{HO}_{2}{ }^{-}+\mathrm{HO}^{\cdot} \rightarrow \mathrm{H}_{2} \mathrm{O}+\mathrm{O}_{2} \quad \mathrm{k}=7.1 \times 10^{9} \mathrm{~L} \mathrm{~mol}^{-1} \mathrm{~s}^{-1} \\
& \mathrm{HO}_{2}{ }^{-}+\mathrm{HO}_{2}{ }^{-} \rightarrow \mathrm{H}_{2} \mathrm{O}_{2}+\mathrm{O}_{2} \mathrm{k}=8.3 \times 10^{5} \mathrm{~L} \mathrm{~mol}^{-1} \mathrm{~s}^{-1} \\
& \mathrm{O}_{2}^{--}+\mathrm{HO}^{-} \rightarrow \mathrm{HO}^{-}+\mathrm{O}_{2} \quad \mathrm{k}=1.01 \times 10^{10} \mathrm{~L} \mathrm{~mol}^{-1} \mathrm{~s}^{-1} \\
& \mathrm{HO}_{2}{ }^{-}+\mathrm{O}_{2}^{--} \rightarrow \mathrm{HO}_{2}^{-}+\mathrm{O}_{2} \quad \mathrm{k}=9.7 \times 10^{7} \mathrm{~L} \mathrm{~mol}^{-1} \mathrm{~s}^{-1} \\
& \mathrm{HO}^{\circ}+\mathrm{HO}^{*} \rightarrow \mathrm{H}_{2} \mathrm{O}_{2} \quad \mathrm{k}=5.2 \times 10^{9} \mathrm{~L} \mathrm{~mol}^{-1} \mathrm{~s}^{-1} \\
& \mathrm{HO}_{2} \cdot+\mathrm{H}_{2} \mathrm{O}_{2} \rightarrow \mathrm{HO}^{*}+\mathrm{H}_{2} \mathrm{O}+\mathrm{O}_{2} \\
& \mathrm{k}=0.5 \mathrm{~L} \mathrm{~mol}^{-1} \mathrm{~s}^{-1} \\
& \mathrm{SO}_{4}^{-{ }^{-}}+\mathrm{H}_{2} \mathrm{O}_{2} \rightarrow \mathrm{SO}_{4}^{2-}+\mathrm{HO}_{2}{ }^{-}+\mathrm{H}^{+} \\
& \mathrm{k}=1.2 \times 10^{7} \mathrm{~L} \mathrm{~mol}^{-1} \mathrm{~s}^{-1} \\
& \mathrm{Cl}^{-}+\mathrm{H}_{2} \mathrm{O}_{2} \rightarrow \mathrm{Cl}^{-}+\mathrm{HO}_{2}^{-}+\mathrm{H}^{+} \\
& \mathrm{k}=1.0 \times 10^{9} \mathrm{~L} \mathrm{~mol}^{-1} \mathrm{~s}^{-1} \\
& \mathrm{Cl}_{2}^{-{ }^{-}+}+\mathrm{H}_{2} \mathrm{O}_{2} \rightarrow 2 \mathrm{Cl}^{-}+\mathrm{HO}_{2}^{-}+\mathrm{H}^{+} \\
& \mathrm{k}=4.1 \times 10^{4} \mathrm{~L} \mathrm{~mol}^{-1} \mathrm{~s}^{-1}
\end{aligned}
$$

Furthermore, using the optimal experimental conditions for the different aqueous matrices, new experiments were carried out by extending the irradiation time to $240 \mathrm{~min}$ for the DW and SW and 360 min for the STP effluent, aiming for higher degradation efficiencies (Figure 3). Under these conditions and considering the limit of detection (LOD) of the equipment $\left(24.8,3.3\right.$, and $0.76 \mu \mathrm{g} \mathrm{L}^{-1}$ for GEM, HCTZ, and NAP, respectively), degradation efficiencies of $95.0,99.3$ and $99.8 \%$ for GEM, HCTZ and NAP, respectively, were obtained in all matrices, with the exception of GEM in the STP effluent (Figure 3). Control experiments (Figures S8 and S9, SI section) using the optimal experimental conditions for each matrix were performed. No significant adsorption (Figure S8) and/or degradation through the oxidizing action of $\mathrm{H}_{2} \mathrm{O}_{2}$ (Figure S9, SI section, open symbols) was obtained, demonstrating that the degradation of the pharmaceuticals occurs by photocatalytic treatment. On the other hand, a significant contribution of $\mathrm{H}_{2} \mathrm{O}_{2} / \mathrm{UV}$-A was obtained (Figure S9, solid symbols). However, comparing these results with the $\mathrm{TiO}_{2} / \mathrm{UV}$-A results (Figures 1a-1f), an improvement in the degradation of the pharmaceuticals was obtained by the coupling of $\mathrm{TiO}_{2}, \mathrm{H}_{2} \mathrm{O}_{2}$, and UV-A (Figures 2a-2f). 

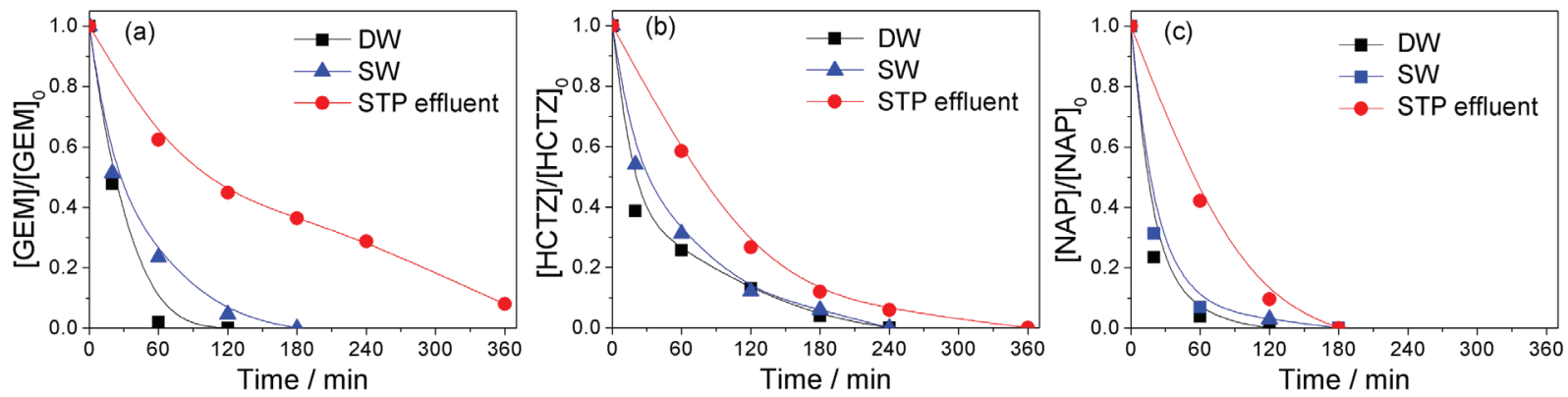

Figure 3. Degradation of the target compounds: (a) gemfibrozil (GEM); (b) hydrochlorothiazide (HCTZ); and (c) naproxen (NAP) by heterogeneous photocatalysis using the best experimental conditions. The initial conditions were the following: $[\mathrm{GEM}]=451 \mu \mathrm{g} \mathrm{L}^{-1}$, [HCTZ] $=536 \mu \mathrm{g} \mathrm{L}{ }^{-1}$, $[\mathrm{NAP}]=413 \mu \mathrm{g} \mathrm{L}^{-1},\left[\mathrm{TiO}_{2}\right]=150 \mathrm{mg} \mathrm{L}^{-1}$, and $\left[\mathrm{H}_{2} \mathrm{O}_{2}\right]=6.0 \mathrm{mg} \mathrm{L}^{-1}$ in DW and $\mathrm{SW}$ at an initial $\mathrm{pH}$ of 5.8-6.0; $\left[\mathrm{TiO}_{2}\right]=450 \mathrm{mg} \mathrm{L}^{-1}$ at an initial pH of 7.4 in the $\mathrm{STP}^{2}$ effluent.

It is important to emphasize that a new sample of STP effluent was used, named STP2 (Table S1, SI section). For this new sample, lower concentrations for most of the analyzed parameters were obtained (Table S1) since the sample was collected during a rainy period. For better comparison with the previous results (Table S3, SI section), using the results present in Figure 3, and considering a pseudo-first-order kinetics model, the values of $\mathrm{k}$ and $\mathrm{t}_{1 / 2}$ were calculated, with the following results: $\mathrm{k}=0.065 \mathrm{~min}^{-1}$ for GEM $\left(\mathrm{t}_{1 / 2}=1.0 \mathrm{~min}\right), 0.012 \mathrm{~min}^{-1}$ for HCTZ $\left(\mathrm{t}_{1 / 2}=1.0 \mathrm{~min}\right)$, and $0.020 \mathrm{~min}^{-1}$ for NAP $\left(\mathrm{t}_{1 / 2}=0.9 \mathrm{~min}\right)$. A difference in the $\mathrm{k}$ values of only 10-13\% was obtained for GEM and NAP, compared to a difference of 39\% for HCTZ (Table S3). Similar behavior was obtained by Soriano-Molina et al. ${ }^{36}$ using the photoFenton process as an alternative to degrade CEC in effluents of five municipal wastewater treatment plants. These same researchers noticed that the nature of the NOM strongly affected the degradation, but not the origin or composition of the effluents. In that work, ${ }^{36}$ the interference of $\mathrm{HCO}_{3}{ }^{-}$ was eliminated by adding $\mathrm{H}_{2} \mathrm{SO}_{4}$ prior to experimentation.

In addition, the mineralization (Figure 4a) and the changes in the acute toxicity of the non-treated and treated

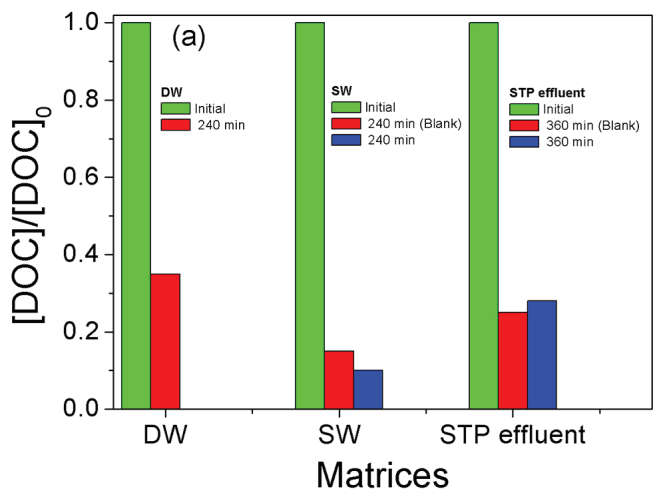

solutions toward the bacteria V. fischeri (Figure 4b) were evaluated.

Complete mineralization was not obtained for any matrix (Figure 4a). According to the results in the DW matrix (free of NOM), by-products were formed with the degradation of the pharmaceuticals since their concentrations were below the LOD of the equipment (Figure 3), and 65\% mineralization was obtained (Figure 4a). Although similar behavior in terms of degradation (Figure 3) and mineralization (Figure 4a) was obtained in the SW and STP effluent matrices, a high residual organic load was present in the SW and STP effluent as a consequence of the greater initial DOC values in these matrices $\left(6.7 \mathrm{mg} \mathrm{L}^{-1}\right.$ in the $\mathrm{SW}$ and $25 \mathrm{mg} \mathrm{L}^{-1}$ in the $\mathrm{STP}^{2}$ effluent). Thus, the toxicity of the treated solution was also evaluated to analyze the behavior of this technology as another method for the treatment of wastewater containing the studied compounds (Figure 4b).

No inhibition in bioluminescence towards V. fischeri was obtained for the initial concentration of the pharmaceuticals in the DW (Figure 4b). This corroborated the results obtained for the initial solutions in SW and STP effluent in the absence and presence of the pharmaceuticals (Figure 4b)

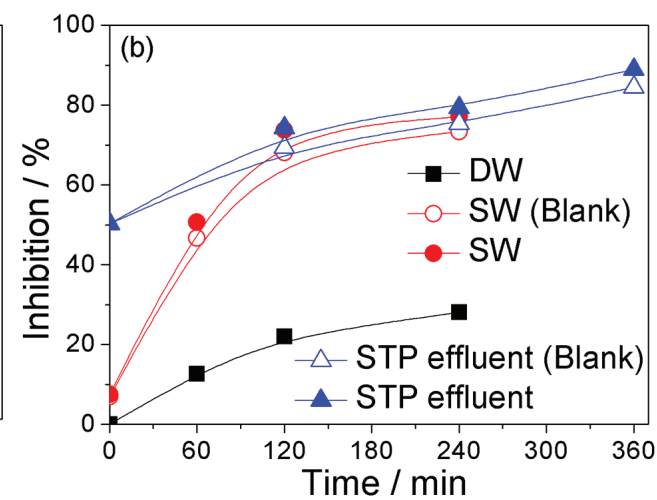

Figure 4. (a) Mineralization and (b) bioluminescence inhibition of the bacteria $V$. fischeri obtained during the degradation of the different environmental aqueous matrices in the absence (open symbols) and presence (solid symbols) of the pharmaceuticals. The initial conditions were the following: $[\mathrm{GEM}]=451 \mu \mathrm{g} \mathrm{L}{ }^{-1},[\mathrm{HCTZ}]=536 \mu \mathrm{g} \mathrm{L}^{-1}$, [NAP] $=413 \mu \mathrm{g} \mathrm{L}^{-1}$, $\left[\mathrm{TiO}_{2}\right]=150 \mathrm{mg} \mathrm{L}^{-1}$, and $\left[\mathrm{H}_{2} \mathrm{O}_{2}\right]=6.0 \mathrm{mg} \mathrm{L}^{-1}$ in the DW and SW at an initial pH of 5.8-6.0; $\left[\mathrm{TiO}_{2}\right]=450 \mathrm{mg} \mathrm{L}^{-1}$ at an initial pH of 7.4 in the $\mathrm{STP}^{2}$ effluent. [DOC] $=0.77,6.7$, and $25 \mathrm{mg} \mathrm{L}^{-1}$ in DW, SW, and STP 2 , respectively. 
since no difference in toxicity was observed. In addition, the higher initial value of inhibition (50\%) obtained in the $\mathrm{STP}^{2}$ effluent was a consequence of the natural components present in this matrix (Figure 4b).

By applying heterogeneous photocatalysis to the DW, an increase in the bioluminescence inhibition from 0 to $28 \%$ was obtained in the DW after 240 min (Figure 4b), indicating that by-products of higher toxicity were generated. Similar behavior was observed in SW and STP effluent matrices (Figure 4b). However, for the real matrices under study, the majority toxicity was due to the by-products formed from the NOM (blank experiments) present in these matrices (Figure $4 \mathrm{~b}$ ) since similar degrees of mineralization were obtained (Figure 4a). Similar behavior was obtained by Michael et al. ${ }^{37}$ during the degradation of a mixture of antibiotics in urban wastewater by the photo-Fenton process under sunlight radiation as a consequence of the oxidation of the dissolved organic matter. ${ }^{37}$ In parallel, these same authors ${ }^{37}$ applied an additional step with granular activated carbon, and almost complete removal of toxicity was obtained. Thus, this procedure can be applied as an alternative method in the removal of the residual toxicity obtained in our work.

\section{Conclusions}

This work demonstrated that the matrix components strongly affects the operational parameters evaluated, which demonstrates the need to evaluate and determine the best operating conditions for each aqueous matrix so as to obtain the maximum degradation efficiency of the target compounds. $\mathrm{A} \mathrm{TiO}_{2}$ concentration that was three times higher and treatment time that was 1.5-3 times longer were required to obtain the same degradation efficiency in the matrix of higher complexity (STP effluent) when compared to the DW and SW. Overall, heterogeneous photocatalysis efficiently degraded the target compounds GEM, HCTZ, and NAP in the matrices studied, being an option for the degradation of this type of pollutant. Besides affecting the operational conditions, rate constants, and removal efficiency, the components of the matrix also affected the toxicity of the solutions after the photocatalytic treatment, requiring a complementary step to remove the residual toxicity.

\section{Supplementary Information}

Supplementary information (chemical structures of the target compounds, control experiments, influence of $\mathrm{TiO}_{2}$ and $\mathrm{H}_{2} \mathrm{O}_{2}$ concentration, and $\mathrm{H}_{2} \mathrm{O}_{2}$ consumption) is available free of charge at http://jbcs.sbq.org.br as PDF file.

\section{Acknowledgments}

The authors thank FAPEMIG (PPM-00509-18), CNPq (Projects 405043/2018-0 and 305215/2018-3), and Laboratory Multiuser of the Institute of Chemistry (Federal University of Uberlândia) for use of the HPLCDAD equipment.

\section{Author Contributions}

Cleiseano E. S. Paniagua, Eduardo O. Marson, Ivo A. Ricardo, Vinícius A. B. Paiva and Bárbara R. Gonçalves were responsible for conceptualization, formal analysis, data curation, methodology, investigation, software, resources, validation, visualization and writing original draft; Alam G. Trovó for the conceptualization, formal analysis, data curation, methodology, funding acquisition, visualization, project administration, writing original draft, review and editing.

\section{References}

1. Richardon, S. D.; Kimura, S. Y.; Environ. Technol. Innovation 2017, 8, 40.

2. K'oreje, K. O.; Okoth, M.; Langenhove, H. V.; Demeestere, K.; J. Environ. Manage. 2020, 254, 109752.

3. Fang, T.-H.; Lin, C.-W.; Kao, C.-H.; Mar. Pollut. Bull. 2019, 146, 509.

4. Liu, M.; Yin, H.; Wu, Q.; Ecotoxicol. Environ. Saf. 2019, 183, 109497.

5. Brumovský, M.; Bečanová, J.; Kohoutek, J.; Borghini, M.; Nizzetto, L.; Environ. Pollut. 2017, 229, 976.

6. Bueno, M. J. M.; Gomez, M. J.; Herrera, G. S.; Hernando, M. D.; Aguera, A.; Fernández-Alba, A. R.; Environ. Pollut. 2012, 164, 267.

7. Grenni, P.; Patrolecco, L.; Ademollo, N.; Di Lenola, M.; Caracciolo, A. B.; Microchem. J. 2018, 136, 49.

8. Paniagua, C. E. S.; Ricardo, I. A.; Marson, E. O.; Gonçalves, B. R.; Trovó, A. G.; J. Environ. Chem. Eng. 2019, 7, 103164.

9. Cabrera-Reina, A.; Martínez-Piernas, A. B.; Bertakis, Y.; Nikolaos, P.; Xekoukoulotakis, N. P.; Agüera, A.; Pérez, J. A. S.; Water Res. 2019, 166, 115037.

10. Alvarez-Corena, J. R.; Bergendahl, J. A.; Hart, F. L.; J. Environ. Manage. 2016, 181, 544.

11. Márquez, G.; Rodríguez, E. M.; Maldonado, M. I.; Álvarez, P. M.; Sep. Purif. Technol. 2014, 136, 18.

12. Jallouli, N.; Elghniji, K.; Hentati, O.; Ribeiro, A. R.; Silva, A. M.; Ksibi, A. M.; J. Hazard. Mater. 2016, 304, 329.

13. Kanakaraju, D.; Motti, C. A.; Glass, B. D.; Oelgemoller, M.; Chemosphere 2015, 139, 579. 
14. Cavalcante, R. P.; Dantas, R. F.; Wender, H.; Bayarri, B.; González, O.; Giménez, J.; Esplugas, S.; Júnior, A. M.; Appl. Catal., B 2015, 176-177, 173.

15. Jallouli, N.; Pastrana-Martínez, L. M.; Ribeiro, A. R.; Moreira, N. F. F.; Faria, J. L.; Adrián, O. H.; Silva, A. M. T.; Ksibi, M.; Chem. Eng. J. 2018, 334, 976.

16. Ismail, L.; Ferronato, C.; Fine, L.; Jaber, F.; Chovelon, J.-M.; Environ. Sci. Pollut. Res. 2018, 25, 2651.

17. Paiva, V. A. B.; Paniagua, C. E. S.; Ricardo, I. A.; Gonçalves, B. R.; Martins, S. P.; Daniel, D.; Trovó, A. G.; J. Environ. Chem. Eng. 2018, 6, 1086.

18. http://www.h2o2.com/technical-library/analyticalmethods/default.aspx ?pid=71\&name=Titanium-OxalateSpectrophotometric, accessed in December 2019.

19. Nogueira, R. F. P.; Oliveira, M. C.; Paterlini, W. C.; Talanta 2005, 66, 86 .

20. ABNT NBR 15411-3: Aquatic Ecotoxicology - Determination of Inhibitory Effect of Aqueous Samples on the Bioluminescence of Vibrio fischeri (Luminescent Bacteria Essay). Part 3: Method Using Freeze-Dried Bacteria; ABNT: Rio de Janeiro, 2012.

21. Hu, X.; Hu, X.; Peng, Q.; Zhou, L.; Tan, X.; Jiang, L.; Tang, C.; Wang, H.; Liu, S.; Wang, Y.; Ning, Z.; Chem. Eng. J. 2020, 380, 122366.

22. Legrini, O.; Oliveros, E.; Braun, A. M.; Chem. Rev. 1993, 93, 671.

23. Buxton, G. F.; Greenstock, C. L.; Helman, W. P.; Ross, A. B.; J. Phys. Chem. Ref. Data 1988, 17, 513.

24. Huang, W.; Luo, M.; Wei, C.; Wang, Y.; Hanna, K.; Mailhot, G.; Environ. Sci. Pollut. Res. 2017, 24, 10421.

25. Gomes Jr., O.; Borges Neto, W.; Machado, A. E. H.; Daniel, D.; Trovó, A. G.; Water Res. 2017, 110, 133.
26. Abdel-Wahab, A.-M.; Al-Shirbin, A.-S.; Mohamed, O.; Nasr, O.; J. Photochem. Photobiol., A 2017, 347, 186.

27. Roushenas, P.; Ong, Z. C.; Ismail, Z.; Majidnia, Z.; Ang, B. C.; Asadsangabifard, M.; Onn, C. C.; Tam, J. H.; Desalin. Water Treat. 2018, 120, 109.

28. Guillard, C.; Puzenat, E.; Lachheb, H.; Houas, A.; Herrmann, J.-M.; Int. J. Photoenergy 2005, 7, DOI 10.1155/ S1110662X05000012.

29. Zhang, W.; Li, Y.; Su, Y.; Mao, K.; Wang, Q.; J. Hazard. Mater. 2012, 215-216, 252.

30. Dimitroula, H.; Daskalaki, V. M.; Frontistis, Z.; Kondarides, D. I.; Panagiotopoulou, P.; Xekoukoulotakis, N. P.; Mantzavinos, D.; Appl. Catal., B 2012, 117-118, 283.

31. Plantard, G.; Azais, A.; Mendret, J.; Brosillon, S.; Goetz, V.; Chem. Eng. Process. 2018, 134, 115.

32. Hassan, M.; Zhao, Y. X.; Xie, B.; Chem. Eng. J. 2016, 285, 264.

33. Reza, K. M.; Kurny, A. S. W.; Gulshan, F.; Appl. Water Sci. 2017, 7, 1569.

34. Nosaka, Y.; Nosaka, A. Y.; Chem. Rev. 2017, 117, 11302.

35. Marson, E. O.; Paiva, V. A. B.; Gonçalves, B. R.; Gomes Jr., O.; Borges Neto, W.; Machado, A. E. H.; Trovó, A. G.; Environ. Sci. Pollut. Res. 2017, 24, 6176.

36. Soriano-Molina, P.; Plaza-Bolaños, P.; Lorenzo, A.; Agüera, A.; García-Sánchez, J. L.; Malato, S.; Sánchez-Pérez, J. A.; Chem. Eng. J. 2019, 366, 141.

37. Michael, S. G.; Michael-Kordatou, I.; Beretsou, V. G.; Jäger, T.; Michael, C.; Schwartz, T.; Fatta-Kassinos, D.; Appl. Catal., B 2019, 244, 871.

Submitted: October 21, 2019 Published online: January 9, 2020 